\title{
Translating Aristophanes' humour for the Modern Greek stage: The Acharnians at the National Theatre of Greece (1961-2005) and the State Theatre of Northern Greece (1991-2010)
}

\author{
Vicky Manteli \\ Hellenic Open University, Greece
}

\section{Abstract}

The paper explores the reception of Aristophanes' first extant comedy 'The Acharnians' (425 $B C)$ in post-war Greek modern theatre by the two government-sponsored theatre institutions of Greece, namely the National Theatre of Greece (NTG) and the National Theatre of Northern Greece (NTNG). It discusses translation trends of Aristophanes' text and focuses on the transference of source text humour in five playscripts, which were all performed from 1961 to 2010. Consequently, it will hopefully address issues of humour translation from a theatrical perspective. The paper applies linguistic tools and humour translation methodology in order to examine source text humour transference in a self-compiled corpus of target texts. I will focus on the paratragedy scene of the comic hero's (Dikaiopolis') visit to the house of Euripides (lines 394-488) in order to show that translators systematically mix verbal and referential humour in their texts, even when source text humour is clearly referential. I will also argue that translators extensively employ play with register, colloquialisms and anachronisms. When viewed historically, recent target texts tend to be 'free adaptations' of Aristophanes' text rather than 'translations'. Following this major conclusion the paper argues that Aristophanes' comedy is culturally relocated by the two government-sponsored Greek stages. This strategy is probably necessitated by the function and the aims of the source text translation and its intended audiences, that is, theatrical performances in open theatres at popular summer festivals viewed by varied audiences of an equally varied assumed level of theatrical and classical sophistication.

Keywords 'The Acharnians, humour translation, theatrical performance 


\section{Theoretical tools and preliminary hypotheses: Humour, translation, and classical drama reception}

The paper explores the reception of humour of Aristophanes' first extant comedy The Acharnians (425 BC) on the Modern Greek stage and particularly by the two major government-sponsored theatre institutions of the country, namely the National Theatre of Greece (NTG) and the National Theatre of Northern Greece (NTNG). It studies the playscripts of The Acharnians (five in total) which were used for the NTG and NTNG productions of Aristophanes' comedy (six in total) since its revival in 1961 and discusses trends in the translation of Aristophanes' comedy. The study addresses the issue of humour translation from a theatrical perspective.

The paper applies linguistic tools and humour translation methodology in order to examine source text humour transference in a self-compiled corpus of target texts. It aims to show that translators systematically mix verbal and referential humour (Attardo 1994; Attardo et al. 1994) in their texts, even when source text humour is clearly referential. Consequently, the present paper provides some tentative answers to the questions raised by Robson (2008: 181) with regard to the usefulness of looking into translators' strategies and 'exploring the precise nature of the divide between verbal and referential humour'. Another point to be explored is that translators extensively play with register, colloquialisms, and anachronisms to compensate for humour loss and add verbal humour in their target texts. When viewed historically, recent translations tend to fit more easily in the category of 'free adaptations' of Aristophanes' comedy than that of 'translations'. Under 'free adaptations' we should consider translation versions which often abandon the literal meaning of source text words and are heavily based on modernising and updating the context of the ancient drama, while 'translations' should be regarded as texts which highly appreciate issues of equivalence (Baker 1992: 5-6) and the relation norm between source text and target text (Chestermann 1997). The latter follow the expectation that 'translations of ancient drama can and should be judged according to the "faithfulness" of their relationship to a linguistically, culturally and sometimes ideologically dominant source text' (Hardwick 2010: 193).

Translation theoreticians have pointed out that cultural relocation or 'acculturation' (Heylen 1993; Aaltonen 1996; Bassnett 1998) is a major issue in the translation of theatre texts and is seen in parallel with 'the expectations of the target audience and the constraints imposed by the theatrical system' (Bassnett 1998: 93). Acculturation, or 'domestication' as Venuti (2000) prefers to name it, should be seen as a negotiation process in theatre translation which runs from preserving the 'exoticism', awkwardness, ambiguity and nuance of the source text, 'through a middle stage of negotiation and compromise' (Heylen in Bassnett 1998: 93) in which such source text features are reduced, and finally comes to a stage where the source text's linguistic, cultural, and historical distinctiveness is eliminated. In the present paper I will argue that cultural relocation (or acculturation) is probably necessitated by the function and the aims of the source text translation and its intended audiences, that is, theatrical performances in open theatres at popular summer festivals viewed by varied audiences of an equally varied assumed level of theatrical and classical sophistication.

Recent studies in the translation of classical Greek theatre challenge classical and historicist interpretative views of the classics and give centre-stage to the mediating role of translation for the survival of the classics and the theatre [1]. Discussion on the translation of classical comedy, in particular, focuses on the relationship between the classical Greek past and the dramatic text's humour [2], on the one hand, and staging the present on the other (Walton 2006). Theatrical discourse on the reception of classical Greek drama seems to pay heed to the kind of the connections between ancient and modern which translations invent and 
renew. It also focuses on the relationship between translation and performance (Hardwick 2003 and 2010). Imbued by such theatrical discourse my work will finally attempt to look into the identity of the assumed 'constructed' audiences and the performance contexts for/in which the Acharnians' playscripts of the NTG and the NTNG were produced.

\section{Mapping The Acharnians at the National Theatre of Greece (NTG) and the National Theatre of Northern Greece (NTNG)}

In this theatrically-oriented section I will give some necessary contextual information concerning the reception of Aristophanes' The Acharnians. It is of particular interest that despite the comedy's revival in the context of the Epidaurus Festival [3] and its permanent presence in major or minor summer festivals of classical drama, commercial productions in major city theatres and/or on tour are practically unknown in Greece. The revival of the comedy in the 20th and 21st centuries has been related both to Modern Greek 'canonised' translations and free adaptations as well as 'landmark' performances while the profile of the stage translators has been quite versatile. Specifically, the comedy has been translated for the stage by renowned philologists, established translators of modern European comedy, translators of classical drama and teachers of drama, prolific translators of Aristophanes and acclaimed writers, directors, journalists, even famous musicians [4]. Since its revival in 1961 until the most updated production in 2010, the number of Modern Greek productions of The Acharnians equals twenty three while the number of translations equals thirteen respectively [5]. Of these twenty three productions one should note that seven were reproductions of the Art Theatre's 1976 production of The Acharnians while another was a musical adaptation. This means that all fifteen new theatre productions of The Acharnians are based on twelve translated texts i.e. for almost every production of Aristophanes a new translation has been commissioned. I would suggest that this almost one-to-one ratio between translated text and performance is necessitated by the conditions of production of the former, the assumption being that the success of Aristophanes' comedy lies on its updating. New target texts have been called for to adjust to the norms of their time and echo the conditions of the theatrical culture and artistic/ideological concepts of the corresponding performances.

In selecting my corpus I was primarily interested in attempting to map the reception of Aristophanes' comedy in post-war Greek modern theatre by the two government-sponsored theatre institutions of Greece. The former institution has produced Aristophanes' comedy four times (1961, 1980, 1995 and 2005). As for the NTNG it has staged Aristophanes' play twice (1991 and 2010). The translated texts I will look into are the texts by Stavrou, Koumanoudis, Spyropoulos, Boukalas, and Myris [6]. It is worth noticing that first, all except one of the translated texts (Koumanoudis's) were commissioned for a specific production. Secondly, Stavrou's close translation has been used twice at the NTG, thus proving, on the one hand its literal value, and, on the other, the performance style of Aristophanes' comedy adopted by the NTG. Third, all translators, but one, have had a long standing career in translating and/or studying Aristophanes. Fourth, all translated texts except one (which is characterised as a 'free adaptation' by the translator himself) have been registered as 'translations'. Finally, all productions were directed by established figures within the tradition of each institution or directors of a broad appeal and theatrical success within the context of the 'free sponsored' theatre. All the above suggests that Aristophanes is a cultural product and a source of interest as well as of box office revenue for the Modern Greek theatre. 


\section{Data analysis}

\subsection{Verbal and referential humour in Aristophanes}

Classical literature research on Aristophanic comic poetry (Dover 1972, Thiercy 2001) discusses Aristophanes' variety of humourous mechanisms, such as wordplay, puns, doubleentendres and innuendo, obscene and taboo language, in-jokes and comic stage business, absurd and utopian dramatic situations and contexts, satire and parody. In his De Oratore (1942) Cicero draws a useful distinction between humour which is on the one hand in verbis and one on the other hand in re. From the viewpoint of humour theories (Attardo 1994) the former can be equated to 'verbal humour' while the latter to 'referential humour'. In the first case, incongruity is produced on the level of language that is, through specific language structures used by the speaker. In other words, verbal humour presupposes a lexicalized connector and resists translation. In the second case incongruity is attached to the content. In other words, referential humour does not presuppose a punning connector or any other formal similarity between words. It is said that referential humour can withstand intra- and interlingual translation. In this section, following Robson's (2008) discussion of the problems of translating Aristophanic humour (see Section 1), I show that Aristophanes is primarily adapted for the Greek stage. By looking into translators' strategies I will explore through the lens of both translation and humour theory the limits of the divide between verbal and referential humour in Aristophanes' source text and the target texts discussed here.

\subsection{The humour of the paratragedy scene (Ach. 394-488). Corpus material.}

In selecting the material (extract from Aristophanes' Acharnians) on which my preliminary hypotheses could be tested, I considered the following three parameters:

1. Aristophanes' remarkably versatile humourous repertoire;

2. the potentially inherent quality of a scene for a sine qua non comic dramatisation on stage;

3. the translators' approach.

I will thus focus on the paratragedy scene of the comic hero Dikaiopolis' visit to the house of tragedian Euripides (Ach., lines 394-488) which, as I will discuss, can be also perceived as a particularly humorous scene in terms of language and of theatrical representation too. In Aristophanic comedy paratragedy refers to any extended or limited intertextual correlation between Aristophanes' text and classical tragedy. It often takes the form of a parodic allusion notably to Euripides' tragedies. The scene is typical of Aristophanes' humour, pregnant with humorous discourse, parodic allusions to Euripides' dramatic technique (Dikaiopolis' target in this scene) and ironic remarks against his family background (specifically against his mother's low class origin and humble profession), metatheatrical references (i.e. Dikaiopolis' self-address rather as an actor than as a character), humorous proper names, neologisms, metaphors, clash between high and low registers (see Section 4.1 in detail). Secondly, in terms of stage representation the scene is humorous and designed to produce laughter since it is built around an extended metaphor according to which the comic hero Dicaeopolis, disguised in rags, is a visual parallel to Euripides' pathetic tragic hero Telephus, a character whom the original audience would probably have recalled upon viewing Aristophanes' comic hero. Like him Aristophanes' hero should face the chorus in the agon and must succeed in his defence. In addition, during the scene the actor speaks out of character and refers to the Acharnians as the comic chorus, pleading Euripides for his help in disguising himself so that, 
unlike the audience, the chorus will not recognise him. With visual humour inherent in this scene one would expect that translators would not need to apply adaptation strategies.

In the paratragedy scene [7] (Ach. 394-488) the comic hero Dicaeopolis visits Euripides to ask for tragic props in order to prepare himself for his defence speech. He persistently begs Euripides for rags and stage props which the tragic poet has already used in his tragedies. By analogy to Euripides' ragged heroes, the comic hero will borrow rags and props that will make him look like a beggar when defending himself in front of the chorus of Aristophanes' comedy and the audience. The scene is full of metaphors parodically staged, the most extensive one being "Dikaiopolis' transformation from suppliant before the Acharnians into suppliant before the Athenians, and at the same time, into suppliant before Euripides" (Russo [1962] 1994: 50). The scene is pregnant with metatheatrical elements attested in the following: Dikaipolis' concern with his performance before the Athenian audience and his defence speech before the Acharnians' chorus is lexicalised in allusions to the hero's representation as a performer rather than as a dramatis persona; these take the form of either explicit or implicit references to the tragic poet's dramaturgy and his family background presented in a derogatory tone. It can be assumed then that humour in this Aristophanic scene is rich and tied up with stage business and props and, thus, easily appreciated by Aristophanes' audience.

The lengthy visit to the poet of Telephus in 394-488 is a typical example of Aristophanes' 'clustered' or 'dense' poetry. [8] It is largely a metatheatrical scene [9] with lots of parodic and paratragic allusions to Euripides as well as both verbal and referential humour. In the next section, I will look into five source text humourous instances (i.e. referential humour), two instances of verbal parody (religious parody) and the dialogic exchange between Euripides' servant and Dikaiopolis at the door-knocking scene vis-à-vis their transference in the target texts, which were used as performative texts (i.e. playscripts) in the productions of the NTG and the STNG. The working hypothesis is that since comic business and referential humour prevail in Ach. 394-488, translators will not need to add verbal humour in their target texts. However, as already stated in Section 1, translators systematically mix verbal and referential humour, thus indicating the divide between the two is far from rigid.

\section{Translating the humour of the paratragedy scene (Ach. 394-488). Source text referential humour}

\subsection{Source text referential humour}

In this section, I will discuss translators' strategies in transferring Aristophanes' humour targeting Euripides' dramatic techniques as well as his family background. Since there is neither verbal play with register clashes, nor punning in these cases, I will consider them as instances of referential humour and examine how it is transferred. In Figure 1, I will first present the source text humorous instances with their English translation by Sommerstein (1980 [1992]). In the figures which will follow, I will give the target texts followed by a gloss. In the discussion parts, normally following each figure with target texts, I will focus on translators' strategies and report conclusions drawn from the analysis of figures. I will also provide some pragmatic information to facilitate comprehension of Aristophanic background. 
Figure 1. Source text metatheatrical in-jokes and referential humour against Euripides with English translation.

\begin{tabular}{|c|c|}
\hline Lines 410-11 & 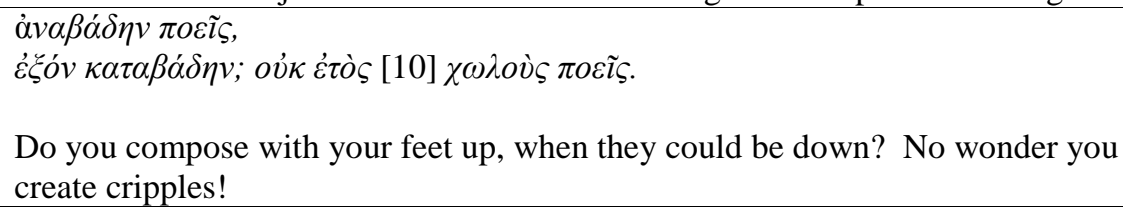 \\
\hline Line 413 & 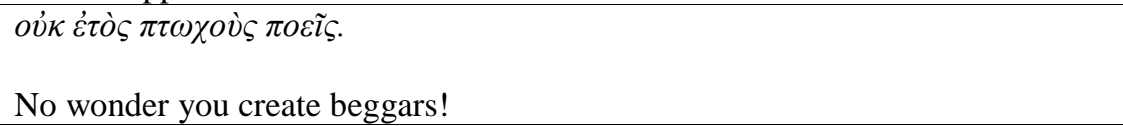 \\
\hline Line 416 & $\begin{array}{l}\delta \varepsilon \tilde{\imath} \gamma \dot{\alpha} \rho \mu \varepsilon \lambda \hat{\varepsilon} \dot{\xi} \alpha l[11] \tau \tilde{\omega} \chi \rho \rho \tilde{\varphi} \dot{\rho} \tilde{\eta} \sigma l v \mu \alpha \kappa \rho \dot{\alpha} v \\
\text { I've got to make a long speech to the chorus }\end{array}$ \\
\hline Line $457 b$ & 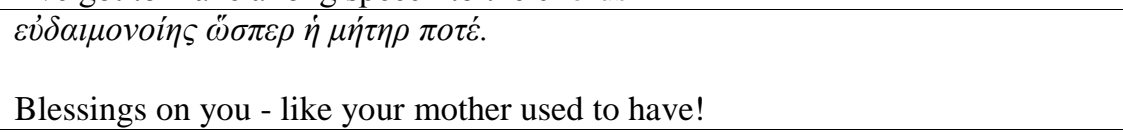 \\
\hline Line 478 & 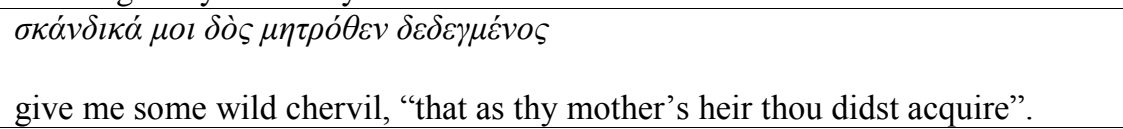 \\
\hline
\end{tabular}

Figure 2. Target texts: Metatheatrical in-jokes in lines 410-11 and 413

\begin{tabular}{|c|c|}
\hline Line 413 & 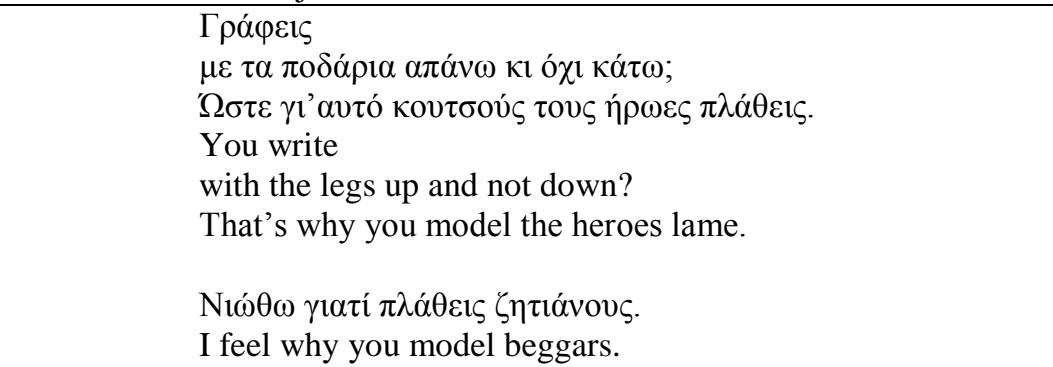 \\
\hline $\begin{array}{l}\text { Koumanoudis } \\
\text { (KOU) } \\
\text { Lines 410-11 }\end{array}$ & 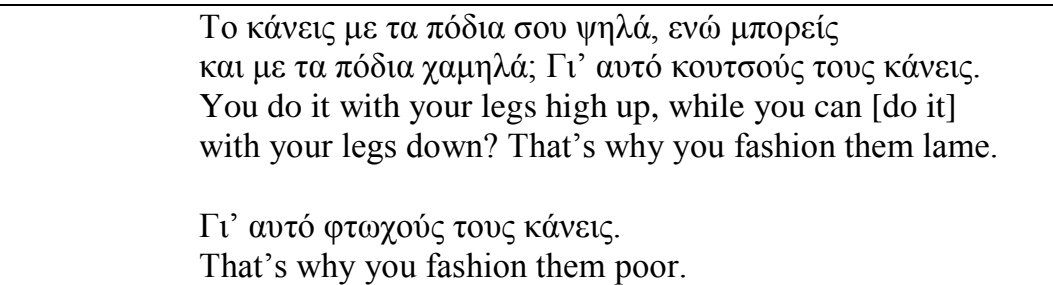 \\
\hline $\begin{array}{l}\text { Spyropoulos } \\
\text { (SPY) } \\
\text { Lines 410-11 }\end{array}$ & 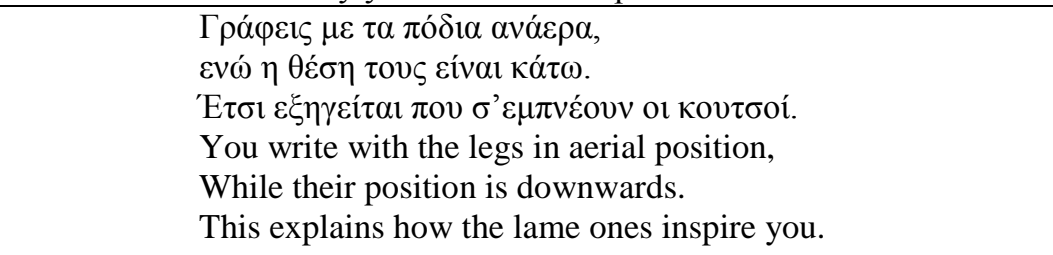 \\
\hline Line 413 & 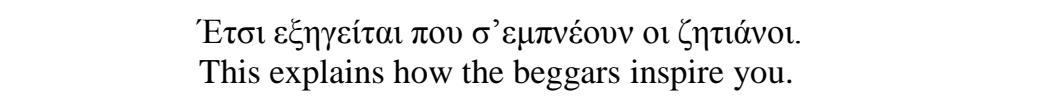 \\
\hline $\begin{array}{l}\text { Boukalas } \\
\text { (BOU) } \\
\text { Lines 410-11 }\end{array}$ & 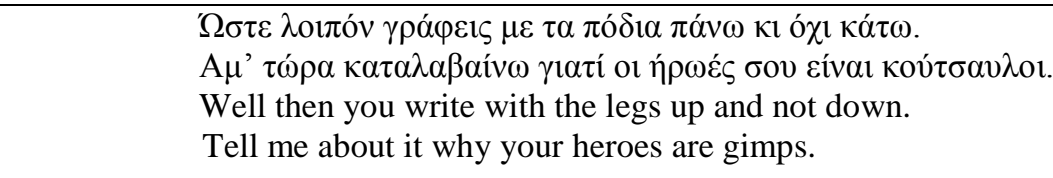 \\
\hline Line 413 & 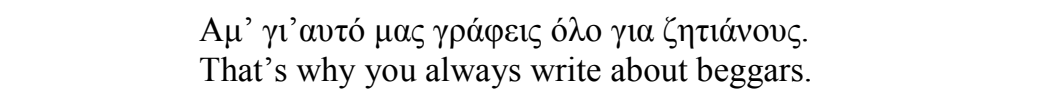 \\
\hline $\begin{array}{l}\text { Myris } \\
\text { (MY) } \\
\text { Lines 410-11 }\end{array}$ & 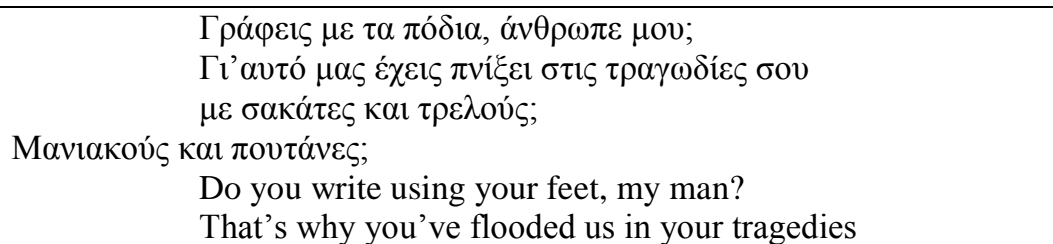 \\
\hline
\end{tabular}


Maniacs and whores?

with crippled and lunatics?

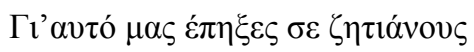

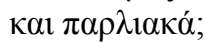

That's why you've flooded us with beggars

and daffy ones?

Lines 410-11 and line 413 can be considered as metatheatrical in-jokes understood and shared by 5th century Athenian audiences who were familiar with Euripides' tragedies. Both contain latent visual parody alluding to Euripides' dramatic technique and motifs. Figure 2 shows that the metatheatrical in-jokes are not domesticated. All translators add explanatory linking words and/or phrases to clarify the causal relationship between Euripides' writing methods and the heroes of his tragedies. Stavrou translates $\omega \sigma \tau \varepsilon$ (that's why), Koumanoudis and Myris repeatedly translate $\gamma \iota ' \alpha \nu \tau o ́$ (that's why), Spyropoulos repeatedly translates ć $\tau \sigma l$

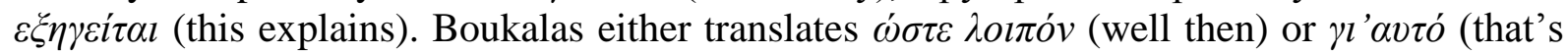
why). This strategy of adding information can be compared to 'explic(it)ation' (Katan 1999: 131) and probably serves the purpose of mediating cultural gaps, since modern audiences are not expected to be as familiar with the humour literature targeting Euripides, as $5^{\text {th }}$ century audiences probably were. It seems then, that foregrounding the causal link between Euripides' writing habits and his tragic heroes is a strategy on which Greek translators rely to compensate for humour loss. In this case

explic(it)ation is not a costly but rather the most appropriate option for preserving the humourous effect in the target text.

Another point which can be drawn from Figure 2 is that most translators play with register by mixing standard with poetic (SPY $\alpha v \alpha \dot{\varepsilon} \rho \alpha$ [in aerial position]), oral (ST $\pi o \delta \alpha ́ \rho ı \alpha$ [legs]; BOU $\alpha \mu^{\prime} \tau \omega^{\prime} \rho \alpha$ [tell me about it]; MY $\pi \alpha \rho \lambda \imath \alpha \kappa \alpha ́$ [daffy]), or low register (BOU

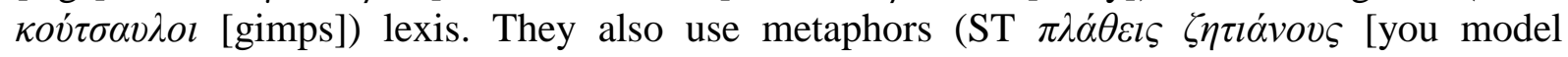
beggars]; MY $\mu \alpha \varsigma \dot{\pi} \pi \eta \xi \varepsilon \varsigma \sigma \varepsilon \zeta \eta \tau \imath \alpha ́ v o v \varsigma$ [you've flooded us with beggars]). The most recent target text, that one by Myris, is clearly an adaptation exploiting taboo language ( $\pi \circ v \tau \dot{\alpha} v \varepsilon \varsigma$ [whores]), a reference to other 'special' categories of heroes in Euripides' drama and a humorous address to the poet, which enhances the theatricality of the text. Therefore, it can be concluded that translators transfer source text referential humour exploiting verbal features, thus mixing referential and verbal humour. Consequently, it can be argued that Greek translators employ verbal play as a means of compensating for the loss of source text referential humour.

Figure 3. Target texts: Dikaiopolis's metatheatrical address as performer

\begin{tabular}{|c|c|}
\hline $\begin{array}{l}\text { Line } 416 \\
\text { (translation by } \\
\text { Sommerstein) }\end{array}$ & I've got to make a long speech to the chorus \\
\hline $\begin{array}{l}\text { ST } \\
\text { Line } 416\end{array}$ & 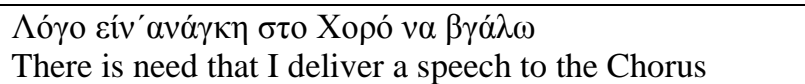 \\
\hline $\begin{array}{l}\text { KOU } \\
\text { Line } 416\end{array}$ & 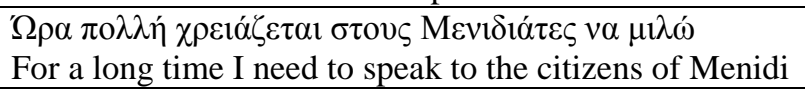 \\
\hline $\begin{array}{l}\text { SPY } \\
\text { Line } 416\end{array}$ & 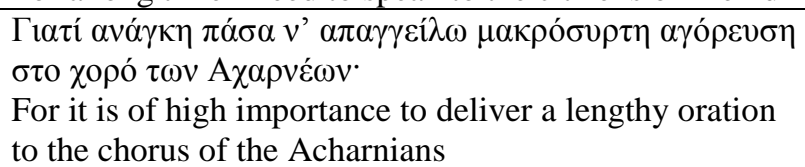 \\
\hline $\begin{array}{l}\text { BOU } \\
\text { Line } 416\end{array}$ & 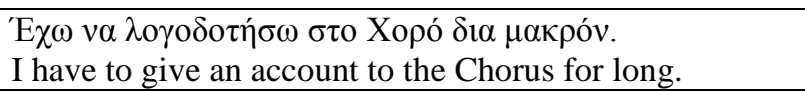 \\
\hline MY & 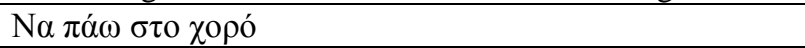 \\
\hline
\end{tabular}




\begin{tabular}{|c|c|}
\hline Line 416 & 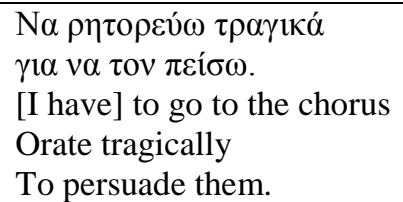 \\
\hline
\end{tabular}

In Line 416 the actor speaks out of character and refers to the Acharnians as the comic chorus. Figure 3 shows that translators often employ high register (the old form of katharevousa) and introduce a formal tone in their texts which potentially creates humour through the ensuing clash between the wrecked appearance of the hero and his use of high register (see SPY and BOU for line 416). Katharevousa is an older form of Modern Greek appropriating formal and learned lexis and structures. It was officially abolished in 1976. Greek humour often rests on register exploitation (Antonopoulou 2002, 2004b; Canakis 1994; Tsakona 2004: 189-200) and particularly the use of katharevousa in ordinary, and, consequently, in inappropriate situations. Such a use results in incongruity realized as incompatibility between language and context. Other texts in Figure 3 (i.e. KOU, SPY) sound more poetic or formal rather than conversational and informal because of the inversion of the standard adjective-noun order. A similar technique is attested in Stavrou's text, in which the standard verb-complement structure is extended so that the complement ( $\lambda \dot{\gamma} \gamma o$ [speech]) is placed in front position.

Figure 4. Target texts: Referential humour targeting at Euripides

\begin{tabular}{|c|c|}
\hline $\begin{array}{l}\text { Line } 457 b \\
\text { Line } 478 \\
\text { (translation by } \\
\text { Sommerstein) } \\
\end{array}$ & $\begin{array}{l}\text { Blessing on you-like your mother used to have! } \\
\text { give me some wild chervil, "that as thy mother's heir thou didst acquire" }\end{array}$ \\
\hline $\begin{array}{l}\text { ST } \\
\text { Line } 457 b \\
\text { Line } 478\end{array}$ & 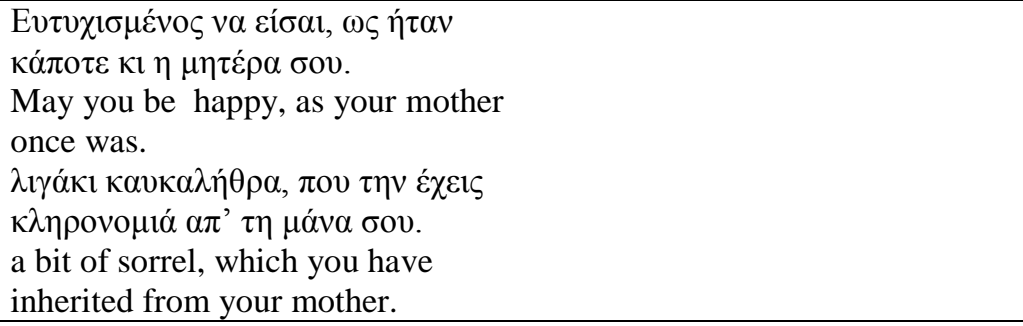 \\
\hline $\begin{array}{l}\text { KOU } \\
\text { Line } 457 b \\
\text { Line } 478\end{array}$ & 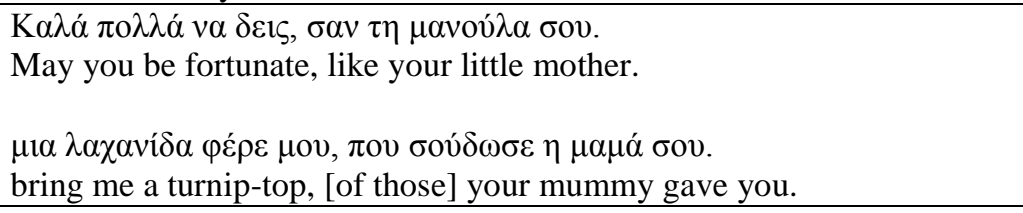 \\
\hline $\begin{array}{l}\text { SPY } \\
\text { Line } 457 b \\
\text { Line } 478\end{array}$ & 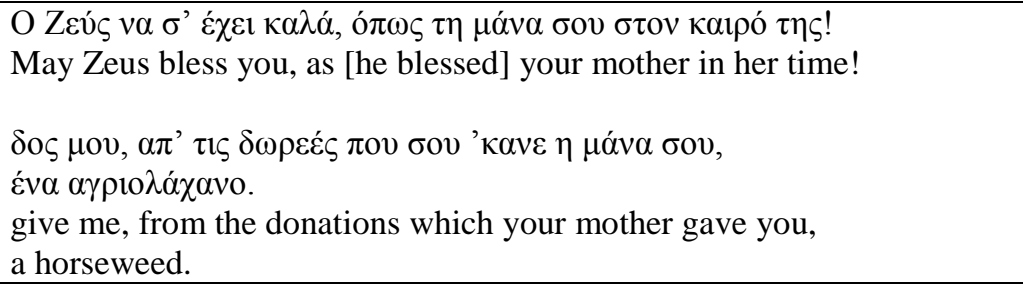 \\
\hline Line 478 & 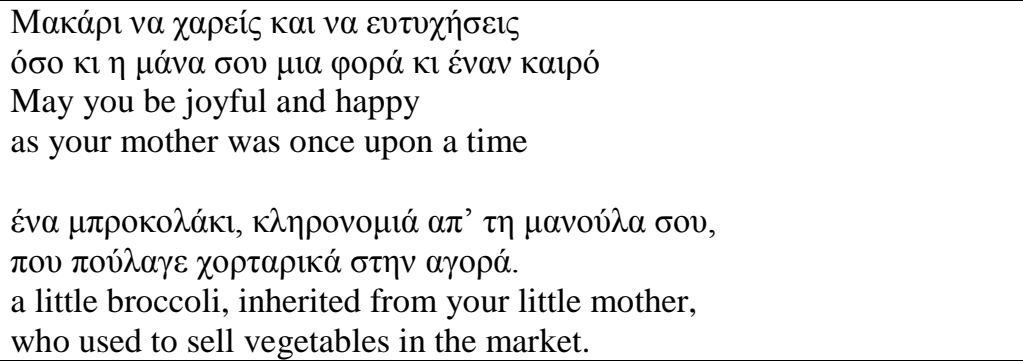 \\
\hline
\end{tabular}




\begin{tabular}{|c|c|}
\hline $\begin{array}{l}\text { MY } \\
\text { Line 457b }\end{array}$ & 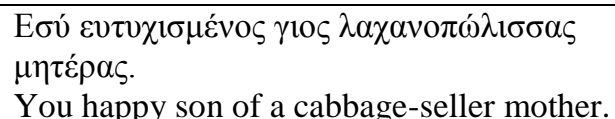 \\
\hline Line 478 & 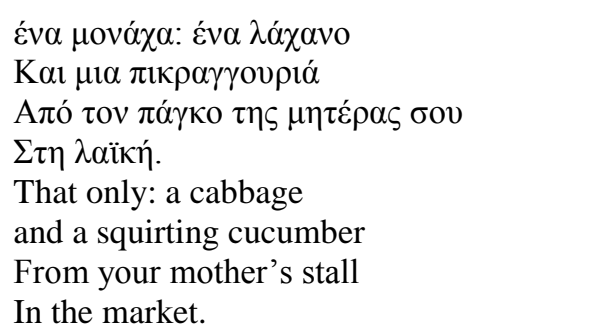 \\
\hline
\end{tabular}

In lines $457 b$ and 478 Euripides' mother is the target of Aristophanes' humour. In the first line, Dikaiopolis suggests that Euripides' mother was of low class, a vegetable vendor at the market and probably easy to be sexually harassed. His phrase might be restated 'as your mother was happy when she walked the streets hawking vegetables' (Olson 2002: 193). Similarly, line 478 Dikaiopolis suggests that Euripides' mother was very poor or lived in utter despair to be fed on $\sigma \kappa \alpha ́ v \delta \iota \kappa \alpha$ (chervil). The line is also a parodic allusion (i.e. verbal humour) to Aeschylus $C h .750 \not ̈ v \varepsilon \dot{\varepsilon} \xi \dot{\varepsilon} \theta \rho \varepsilon \psi \alpha \mu \eta \tau \rho o ́ \theta \varepsilon v \delta \varepsilon \delta \varepsilon \gamma \mu \varepsilon \dot{\varepsilon} \eta \eta$ ('whom I brought up, having got him from his mother', a reference to Orestes) (Olson 2002: 196).

The satire against Euripides' mother in lines $457 b$ and 478 is primarily transferred through explic(it)ation, attested as explanatory details about the profession of Euripides' mother or as added information concerning the mode according to which Euripides finds himself to possess different sorts of vegetables. Stavrou, Spyropoulos and Boukalas specify that Euripides inherited his mother's 'property' (i.e. different sorts of vegetables). Boukalas and Myris explain Euripides' mother's profession. In addition, all translators play with register either in the form of humourous addresses ( $\eta \mu \alpha \mu \alpha$ oov [your mummy]), diminutives

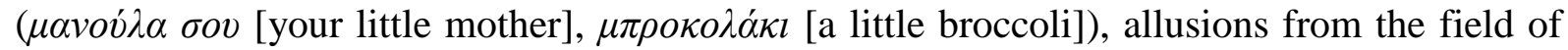

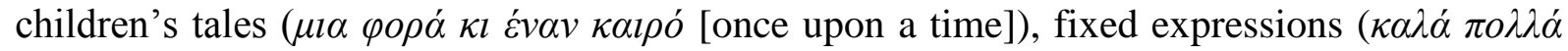
$v \alpha \delta \varepsilon l \varsigma$ [may you be fortunate). Target text verbal humour is also enhanced by reconstructing

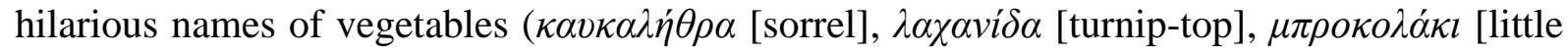
broccoli], $\pi \iota \kappa \rho \alpha \gamma \gamma o v \rho \iota \alpha ́$ [squirting cucumber]) and incongruous collocations (happy son of a cabbage-seller mother). As shown in other cases, Stavrou's target text (i.e. the oldest) is the one closest to the original, while Myris's (i.e. the most recent) is clearly an adaptation.

\subsection{Two cases of religious parody: Ach. 404-6 and Ach. 435}

Here I am analyzing two more Aristophanic examples:

Ev̉

Euripides, beloved Euripides, answer my call, if ever thou didst answer any mortal.

(Translated by Sommerstein)

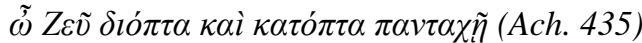

"O Zeus who seest through and under all"

(Translated by Sommerstein)

Both are cases of religious humour encompassing verbal and referential humour (see Manteli 2011: 92-94). The former should be viewed as a paradoxical invocation. The typical structure of prayer is used by the comic hero to address a mortal rather than a divinity. "Dikaiopolis begs Euripides to open the door and grant him the favour of his presence, something which 
the tragic poet notoriously avoids doing. ST [source text] humour is enhanced through the

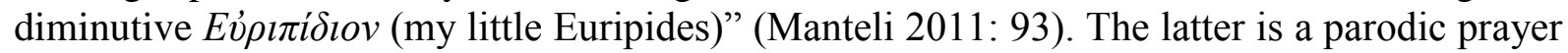
to Zeus, in which a paradoxical invocation is followed by an unexpected use of adjectives.

From the analysis of the target texts it becomes clear that Aristophanes' use of the

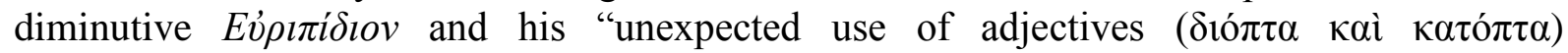
incongruously qualifying the divinity" (Manteli 2011: 94) are reconstructed by Modern Greek translators as a means of transferring the religious parody of the source text. This assumption

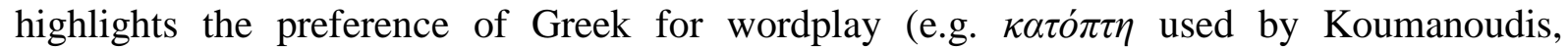
$\pi \alpha \nu \tau \varepsilon \pi \delta \dot{\pi} \tau \eta$ used by Myris) exploiting compounds and derivational suffixation (Antonopoulou 2004b: 64). In addition, translators transfer the source text diminutive Evol $i \delta l o v$ through

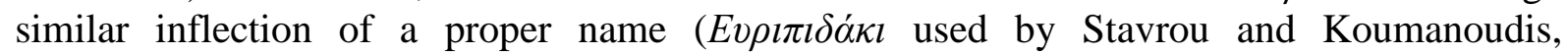

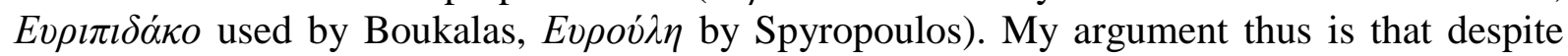
cultural relocation necessitated by theatre adaptation, translators employ equivalent punning mechanisms to transfer the source text's verbal humour. This finding about ancient Greek and Modern Greek, considered two versions of the same language, can be taken as an extension to Delabastita's (1996: 135-139) hypothesis that similar punning mechanisms can be found among morphologically similar languages. This finding may be of interest for intralingual humour translation and the morphological characteristics shared by Classical and Modern Greek. Furthermore, in line 435 the religious invocation and reference to Zeus is either transferred as such (i.e. reference to Zeus) or relocated ( $\Theta \varepsilon \varepsilon \dot{\varepsilon} \mu o v$ [Oh my God] by Myris). Nevertheless, Greek translators opt for an anachronistic transference of source text religious parody through anachronistic religious qualifications ( $\pi \alpha v \tau o \kappa \rho \dot{\tau} \tau o \rho \alpha$ [Almighty], $\pi \alpha v \tau o \delta v v v \alpha \mu \varepsilon$ [Omnipotent], $\pi \alpha \nu \tau \varepsilon \pi \delta ́ \pi \tau \eta$ [All-seeing]) attributed to God in the Greek Orthodox Church and puns based on polysemy ( $\kappa \alpha \tau o ́ \pi \tau \eta$ [surveyor and literally the one who sees under all]). All the above suggests that Modern Greek translators use domesticating strategies when translating Aristophanes' Acharnians for the stage. It implies that the performance texts are culturally relocated so that they contain linguistic and cultural referents which are fluent and transparent enough to be appreciated by large Modern Greek audiences.

\subsection{The door-knocking scene (Ach. 395-409)}

Here I will look into how translators transfer Dikaiopolis' humourous appreciation of the

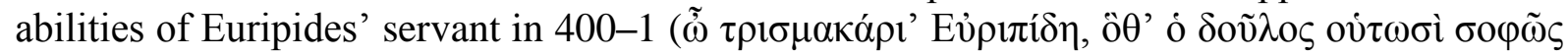
$\dot{\alpha} \pi \varepsilon \kappa \rho i ́ v \alpha \tau$ [How happy is Euripides, when his very slave produces such clever interpretations!], transl. by Sommerstein), the allusive proper name in 406 (Xo $\lambda \lambda \eta \dot{\eta} \delta \eta \varsigma$ [of Cholleidae], transl. by Sommerstein), as well as the reference to the theatrical stage machinery (ekkuklema) in $407\left(\Delta \mathrm{t} . \dot{\alpha} \lambda \lambda \lambda^{\prime} \dot{\varepsilon} \kappa \kappa \nu \kappa \lambda \dot{\eta} \theta \eta \tau^{\prime}\right.$ [Then have yourself wheeled out],

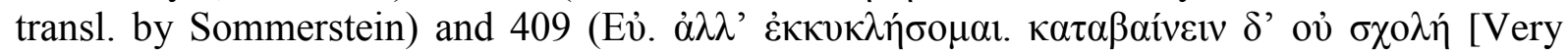
well, I'll have myself wheeled out: I've no time to get down], transl. by Sommerstein). I will also discuss cases of global 'transposition' (Silk 2007: 290), i.e. adaptation. The latter involves any attempts taken by translators for cultural transposition and updating (see Section 1.).

Figure 5 shows that the address of lines $400-1$ is mostly transferred by a standard Modern Greek expression alluding to Euripides' good luck in possessing such a wise servant. The reference to Euripides's servant's qualities are equated with wisdom and communicative skills as in the source text (Stavrou, Koumanoudis, Boukalas, Myris) or reconstructed as acting ability in particular (Spyropoulos). The latter can be viewed as part of a global strategy of adding metatheatrical humour to compensate for possible loss of metatheatrical in-jokes attested elsewhere in the source text (see line 409). This strategy of text adaptation is widely 
employed, as will be further shown, by Myris who replaces the source text adverb $\sigma 0 \varphi \tilde{\omega} \varsigma$

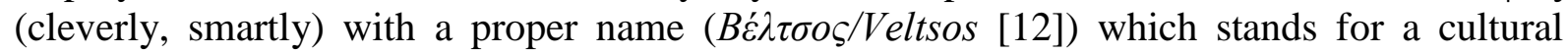
stereotype with specific connotations, i.e. highly educated and sophisticated, producing largely complicated and incomprehensible discourse. Apart from this, Koumanoudis and Boukalas's target texts indicate preference for low register choices and colloquialisms, thus adding verbal humour in their target texts. As already stated (see 4.1. and 4.2), extensive play with register and use of colloquialisms are common strategies to compensating for the humour loss.

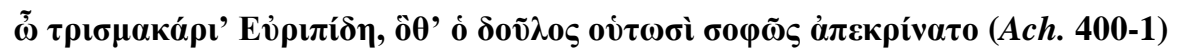

("How happy is Euripides, when his very slave produces such clever interpretations!", translated by Sommerstein)

Figure 5. Humourous address to Euripides with a gloss

\begin{tabular}{|c|c|}
\hline Stavrou (ST) & 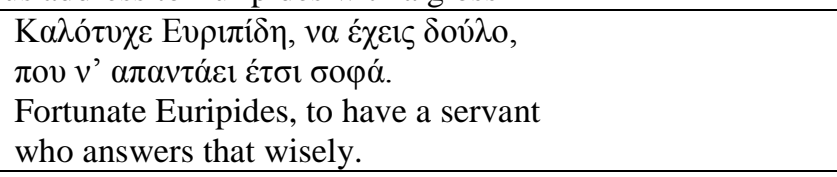 \\
\hline $\begin{array}{l}\text { Koumanoudis } \\
\text { (KOU) }\end{array}$ & 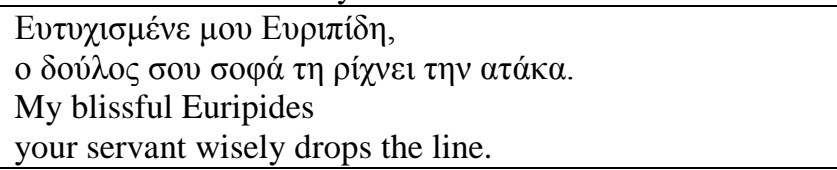 \\
\hline $\begin{array}{l}\text { Spyropoulos } \\
\text { (SPY) }\end{array}$ & 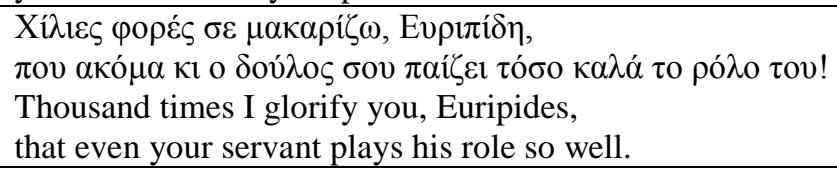 \\
\hline $\begin{array}{l}\text { Boukalas } \\
\text { (BOU) }\end{array}$ & 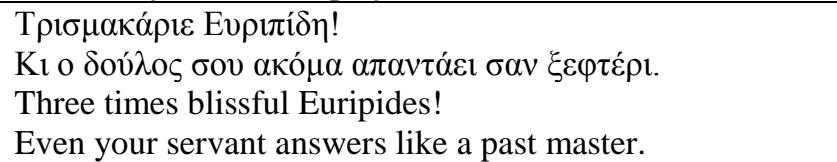 \\
\hline $\begin{array}{l}\text { Myris } \\
\text { (MY) }\end{array}$ & 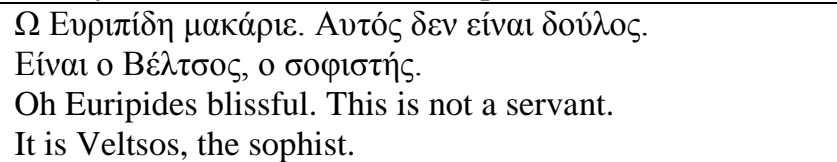 \\
\hline
\end{tabular}

On line 406 Dikaiopolis introduces himself as $X o \lambda \lambda \eta \eta \dot{\delta} \eta \varsigma$ (of the municipality of Cholleidai), an allusive proper name with a punning effect on $\chi \omega \lambda o ́ \varsigma$ (lame) and probably a joke targeting Euripides' preference for writing about crippled heroes. Stavrou and Koumanoudis preserve

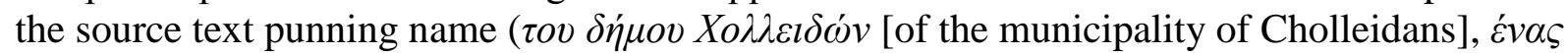
$X o \lambda \lambda \varepsilon i \delta \eta \varsigma$ [a Cholleidan]) but it is not obvious that the referents of the allusive proper name can be identified by modern audiences [13]. Spyropoulos and Myris replace the allusion by target text proper names which keep echoic, paronymic resemblance to the source text name

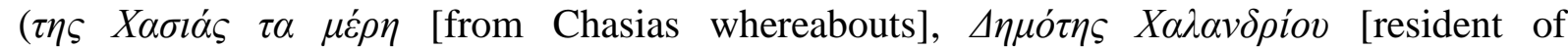

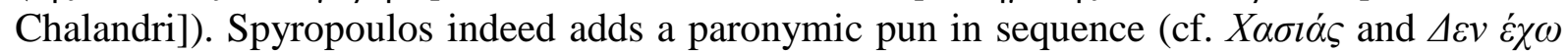

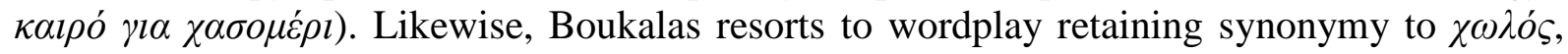

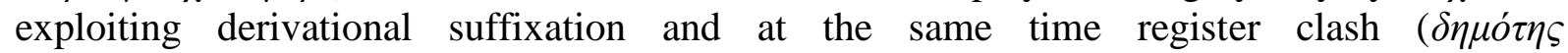

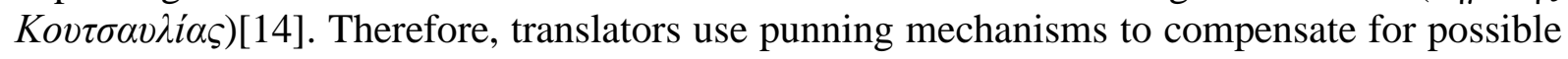
humour loss depending on source text cultural referents.

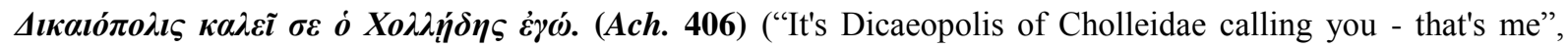
translated by Sommerstein)

Figure 6. Dikaiopolis' introduces himself to Euripides (target texts with a gloss)

\begin{tabular}{|c|}
\hline 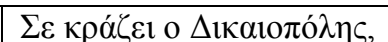 \\
\hline
\end{tabular}




\begin{tabular}{|c|c|}
\hline & $\begin{array}{l}\tau \text { ov } \delta \eta \mu \rho v \tau \omega v \text { Xo } \lambda \lambda \varepsilon 1 \delta \omega \dot{v} . \\
\text { Dikaiopolis is crying out for you } \\
\text { of the municipality of Cholleidans }\end{array}$ \\
\hline $\begin{array}{l}\text { Koumanoudis } \\
\text { (KOU) }\end{array}$ & 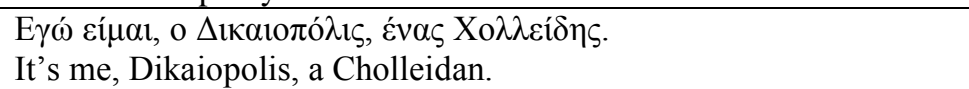 \\
\hline $\begin{array}{l}\text { Spyropoulos } \\
\text { (SPY) }\end{array}$ & 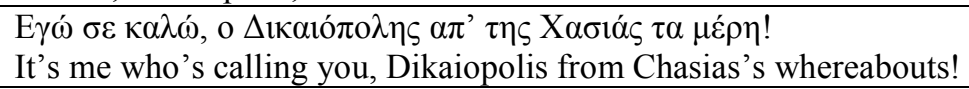 \\
\hline $\begin{array}{l}\text { Boukalas } \\
\text { (BOU) }\end{array}$ & 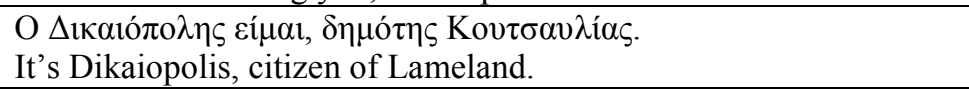 \\
\hline $\begin{array}{l}\text { Myris } \\
\text { (MY) }\end{array}$ & 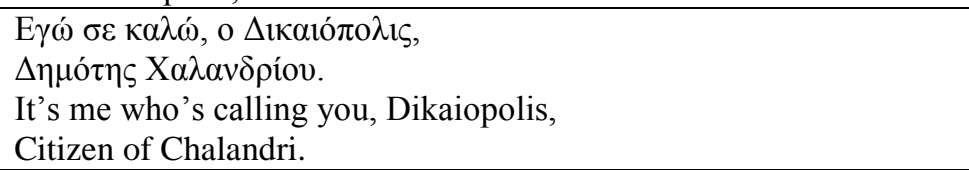 \\
\hline
\end{tabular}

As for the transference of the metatheatrical humour in 407 and 409, which matches with a specific visual comic representation on stage with the tragic poet appearing on stage on the stage machinery rather than on foot, it is reproduced in all target texts with some kind of explic(it)tation (except for Stavrou who transfers rather vaguely) when transferring 409 and

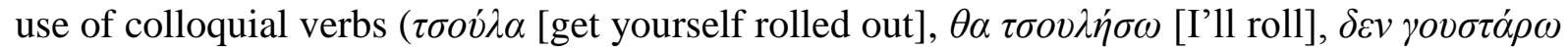
[I don't fancy]) and informal direct address ( $\pi \alpha l \delta \alpha \dot{\kappa} \kappa l \mu o v$ [my little child]). It is then clear that play with register is adopted by most translators in a scene which is in any case designed to provoke laughter.

Figure 7. Explic(it)ation of the metatheatrical humour in lines 407 and 409 with gloss.

\begin{tabular}{|c|c|}
\hline Stavrou (ST) & 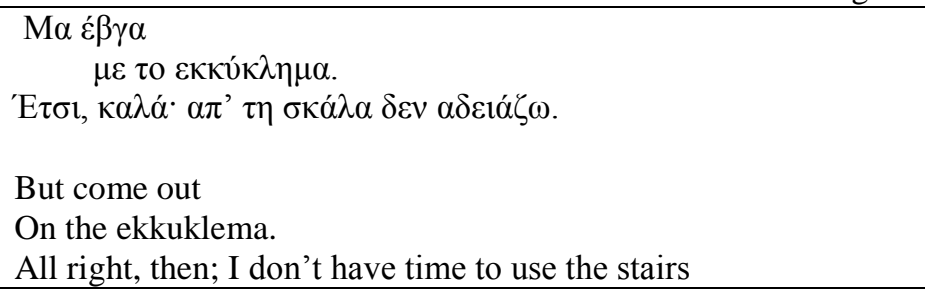 \\
\hline $\begin{array}{l}\text { Koumanoudis } \\
\text { (KOU) }\end{array}$ & 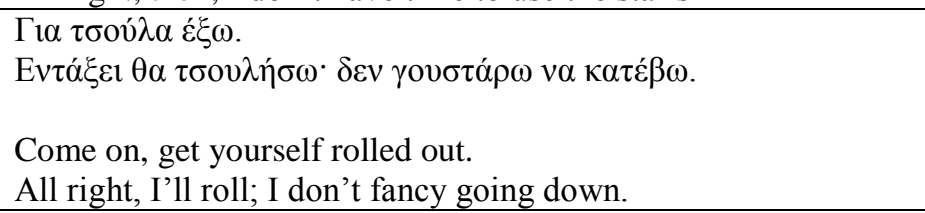 \\
\hline $\begin{array}{l}\text { Spyropoulos } \\
\text { (SPY) }\end{array}$ & 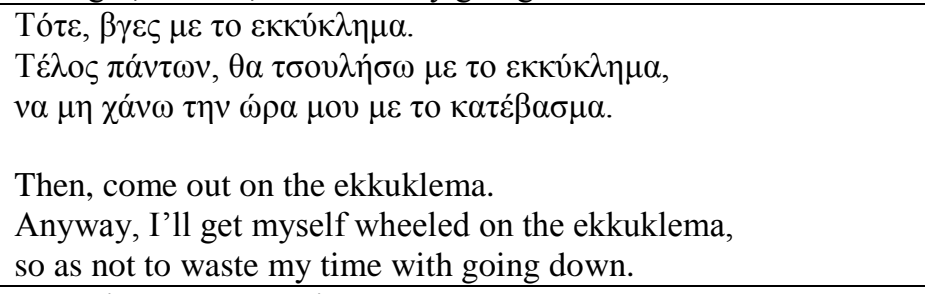 \\
\hline $\begin{array}{l}\text { Boukalas } \\
\text { (BOU) }\end{array}$ & 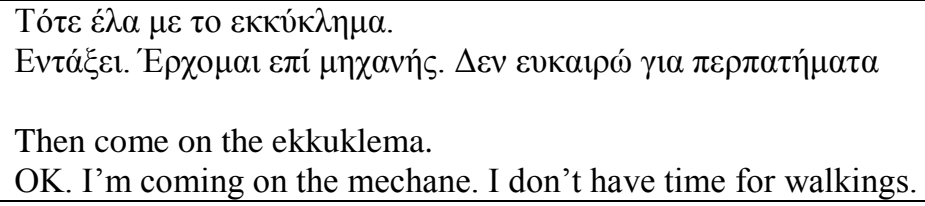 \\
\hline Myris (MY) & 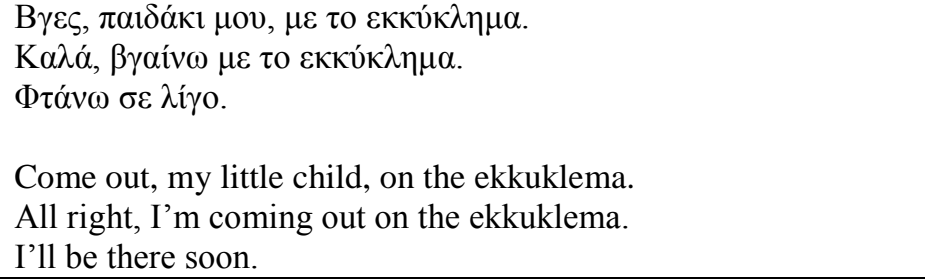 \\
\hline
\end{tabular}




\section{Discussion and conclusions}

The present study has shown that two global strategies are recurrent in the translation of Aristophanes' first extant comedy The Acharnians by Modern Greek translators, who have often been commissioned to translate for the two major state-governed Greek theatres, the NTG and the NTNG, in the context of the major open-air summer festivals. These are compensation and acculturation/domestication. As already discussed, the latter is related to adaptation.

With (visual) humour and comic business inherent in the Aristophanic extract studied (Ach. 394-488), one would expect that translators would not need to apply adaptation strategies and add verbal humour in their target texts. However, domestication and, more particularly, adaptation in more recent playscripts are the most popular translation strategies which result in updated, colloquial, humourous texts, easily received in performance by a wide audience without expert knowledge of Aristophanic texts. Modern Greek translators use domesticating strategies, such as use of linguistic and cultural referents, which are fluent and transparent enough to be appreciated by large Modern Greek audiences.

The analysis in Sections 4.1., 4.2., and 4.3. as well as particularly the examples by Myris show that the more recent an Aristophanic production, the more culturally relocated (or acculturated or domesticated) Aristophanes' text is. Cultural relocation seems to be necessitated by the function and the aims of the source text translation and its intended audiences, that is, theatrical performances in open theatres at popular summer festivals viewed by varied audiences of an equally varied assumed level of theatrical and classical sophistication. One could purport that a large proportion of audiences tend to appreciate a good laugh ensuing from punning devices, obscenities, and anachronisms (which are more common in Greek TV humour) rather than the comic business of the play. The case of translating religious parody (see Section 4.1.2.) is a case in point.

Compensation is related to explic(it)ation, a strategy of adding information for purposes of mediating cultural gaps when referential humour and satire is involved (see Section 4.1.1.). Explic(it)ation is also employed when adding metatheatrical humourous references to compensate for source text metatheatrical humour loss (see Section 4.1.1.).

The paper demonstrates the preference of the Greek language for wordplay allowed by the morphological system of the language, namely wordplay exploiting compounds and derivational suffixation. As for verbal humour transference in particular, the paper shows that despite cultural relocation necessitated by theatre adaptation, translators employ equivalent punning mechanisms to transfer the source text's verbal humour, specifically diminutives in religious parody (see 4.2.). This may be seen as an extension to Delabastita's (1996) hypothesis that similar punning mechanisms can be found not only among morphologically similar languages but also among different chronological versions of the same language. It seems then that this finding may be of interest for intralingual humour translation and the morphological characteristics shared by Classical and Modern Greek. Data analysis in Section 4 demonstrates that Greek translators employ play with register (Baker 1992; Attardo 1994, 2001) as a means of compensating loss of source text referential humour. They systematically mix verbal and referential humour in their texts, even when source text humour is clearly referential. Translators extensively play with register, colloquialisms, and anachronisms as common strategies for compensating (referential) humour loss. Specifically, they use punning mechanisms to compensate for possible humour loss depending on source text cultural referents (see Figure 3). Consequently, they transfer source text referential humour by exploiting verbal features, thus mixing referential and verbal humour. This may be viewed as a valuable finding concerning the conceptualization of the divide between verbal and 
referential humour in Aristophanes in translation and, thus, add to the respective literature, as Robson has suggested (see Section 1.1. and Section 3.1.).

From all the above it becomes clear that Aristophanes is culturally relocated by the two national theatre organisations meaning that the playscripts used by the NTG and the NTNG tend to localize The Acharnians in time and place. In other words, in its theatrical representation(s) Aristophanes' comedy is 'transposed' (see Silk 2007) from its 5th century culture to the present culture, 'such that, at the point of transposition, the past (if past) is necessarily made present' (Silk 2007: 290, my emphasis). Aristophanes in performance on the NTG and the NTNG becomes an accessible writer, culturally relocated, and based on the Greek language repertoire of verbal humour as well as on updated humorous mechanisms. Aristophanes' play revives on the NTG and the NTNG through commissioned productions whose emphasis on the present and the contemporary culture outweighs the classic or exotic quality of the 5th century culture. Consequently, my paper adds to the discussion on the translation of classical comedy in that it particularly shows how Aristophanes is transferred on the Modern Greek stage and particularly how his comedies are represented by the two Greek major institutionalized theatres. These considerations help theorists and practitioners to reconsider the -convenient but resilient- notion of equivalence in the translation and reception of classic comedy (Hardwick 2003: 64-66). They also help them to focus on more pragmatic dilemmas, such as how translators and modern audiences of Aristophanes appreciate the poet's humour and what exactly they find worthy to be performed on the modern stage.

\section{Acknowledgements}

The author is grateful to Eleni Antonopoulou and Villy Tsakona for their insightful comments on the present paper.

\section{Notes}

[1] On translation and the importance of the role of translator in mediating the message of the classical text see Walton (2006: 196). On the translation of classical drama and its performability see Walton (2008: 261-77). Lianeri and Zajko discuss the problem posed by translation with regard to the kind of historicity and classicism that need to be explained in a post-colonial era see Lianeri and Zajko 2008: $4,8-9,15,16-7)$. On literary translation as a cultural medium between two systems of language and culture and the 'cultural turn' in translation studies, see Bassnett (1998: 90-108).

[2] On Aristophanes' qualities as a comic poet and dramatist and on the humour of its comedies see Thiercy 1999: 46-50 and also Dover (2003), particularly chapters 3, 4 and 5.

[3] The Epidaurus Festival officially opened in the ancient theatre of Epidaurus in 1954 and has ever since been the most popular site for the performance of Greek comedy and tragedy. It has also been the most influential institution for the performance of classical drama in contemporary Greece which affected directors' approaches and audiences' response to classical drama reception. Other famous sites for the performance of classical drama are the Athens Festival hosted at Herodes Atticus Theatre in Athens since the 1950s and a list of regional and municipal festivals in other open-air, in many cases ancient, theatres around Greece which stage classical drama performances during the summer season.

[4] This finding can be compared to Stephanopoulos' (2011) discussion of the translation of Greek tragedy. In discussing the recent tradition of the translations of classical tragedy at the National Theatre of Greece Stephanopoulos (2012: 309) remarks that during the last decade translations have been more than often commissioned to directors, playwrights and poets, rather than to classical philologists as the tradition held in the past since the 1960s.

[5] For a humour-oriented and translatological discussion of all playscripts as well as a performance analysis of the theatrical productions of The Acharnians in revival on the Greek stage up to 2008 see Manteli (2008). 
[6] For bibliographical details see the list of 'Greek target texts' in 'Primary sources'.

[7] See Rau (1967: 19-114) for a comprehensive examination of Aristophanes' explicit use of tragedy.

[8] For the terms 'density' and 'clusters' in Aristophanes' comedy see Silk (2000 and 2007: 287-308)

[9] More on Aristophanes' metatheatre in the Acharnians see Slater (2002: 42-67).

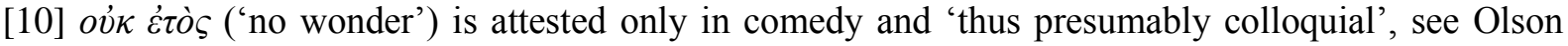
(2002: 181).

[11] The 1st aorist of $\lambda \dot{\varepsilon} \gamma \omega$ indicates poetic vocabulary, see Olson 2002: 182.

[12] Yiorgos Veltsos, a philosopher, communications specialist, poet and playwright, is professor at the Department of Communication, Media, and Culture of Panteion University, Athens. His name has passed into Modern Greek slang evoking both positive and negative connotations. In the former case, 'Veltsos' stands for the omniscient specialist and the enlightened spirit. In the latter, it stands for the vain, know-all windbag.

[13] For a discussion of interlingual transference of allusive proper names and their contribution to humorous effect see Antonopoulou (2004a). See also Leppihalme $(1994,1997)$ for an exploration of the strategies adopted by translators for this linguistic category.

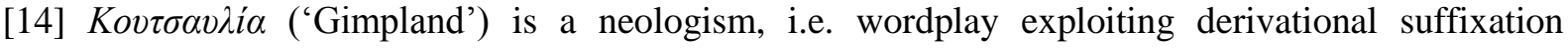

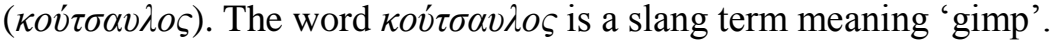

\section{Primary sources}

\section{Source text}

Olson, D. S., ed. (2002), Aristophanes “Acharnians”. Oxford: Oxford University Press.

\section{Greek target texts}

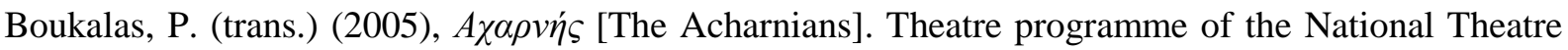
of Greece, summer 2005.

Koumanoudis, St. N. (trans.) (1985), A $\chi \alpha \rho v \dot{s}$ [The Acharnians]. Athens: Typografeio Keimena.

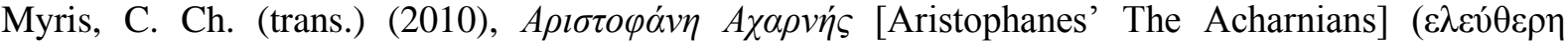
$\mu \varepsilon \tau \alpha \dot{\varphi} \varphi \rho \alpha \sigma \eta$ free translation), Athens, typescript.

Spyropoulos E. (trans.) (1998), A $\alpha \rho \rho \varepsilon \varepsilon i \varsigma$ [The Acharnians]. Athens: Patakis.

Stavrou, Thr. (trans.) (2004), $\triangle \eta \mu o ́ \tau \varepsilon \varsigma ~ \tau \omega v ~ A \chi \alpha \rho v \omega ́ v$ [Citizens of Acharnae]. In Thr. Stavrou $O l$

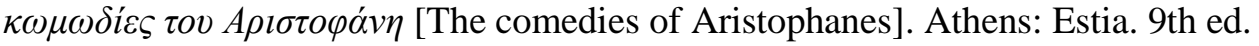

\section{English target text}

Sommerstein, A. H., ed. (1980), Acharnians: The Comedies of Aristophanes. Vol.1 (with translation and notes). Wiltshire: Aris \& Phillips Ltd.

\section{References}

Antonopoulou, E. (2002). 'A cognitive approach to literary humour devices: Translating Raymond Chandler'. The Translator: Studies in intercultural communication 8 (2), pp. 195-220.

Antonopoulou, E. (2004a). 'Humour theory and translation research: Proper names in humourous discourse'. HUMOUR 17(3), pp. 219-255.

Antonopoulou, E. (2004b). Humour in Interlingual Transference. Athens: Parousia.

Attardo, S. (1994). Linguistic Theories of Humour. Berlin: Mouton de Gruyter.

Attardo, S., Attardo D. H., Baltes P., \& Petray M.J. (1994). 'The linear organization of jokes: statistical analysis of two thousand texts'. HUMOUR, 7(1), pp. 27-54. 
Attardo, S. (2001). Humourous Texts: A Semantic and Pragmatic Analysis. Berlin \& New York: Mouton de Gruyter.

Baker, M. (1992). In Other Words. A coursebook on translation, London \& New York: Routledge.

Bassnett, S. (1998). 'Still Trapped in the Labyrinth: Further Reflections on Translation and Theatre', in S. Bassnett and A. Lefevere, (eds.), Constructing cultures. Essays on literary translation, Clevendon: Multilingual Matters, pp. 90-108.

Canakis, C. (1994). 'Diglossia as an agent of humour in the writing of Helena Akrita'. Journal of Modern Greek Studies 12, pp. 221-237.

Cicero (1942), De Oratore, trans. E. W. Sutton, intr. H. Rackham. London: Heinemann.

Delabastita, D. (1996). 'Introduction'. The Translator 2(2), pp. 127-139.

Dover, K. J. (2003) [1972]. I Komodia tou Aristophani [The Aristophanic Comedy]. trans. F. I. Kakridis. Athens: MIET. [in Greek]

Hardwick, L. (2003). 'Reception Studies'. Greece \& Rome 33, pp. 61-66.

Katan, D. (1999). Translating Cultures. An Introduction for Translators, Interpreters and Mediators. Manchester: St. Jerome Publishing.

Leppihalme, R. (1994). 'Translating allusions: When minimum change is not enough'. Target 6 (2), pp. 177-193.

Leppihalme, R. (1997). Culture Bumps. An Empirical Approach to the Translation of Allusions. Clevendon/Philadelphia: Multilingual Matters.

Lianeri, A. \& Zajko V. (2008). 'Introduction. Still Being Read after so Many Years: Rethinking the Classic through Translation', in A. Lianeri and V. Zajko, (eds.), Translation \& the Classic. Identity as Change in the History of Culture, Oxford \& New York: Oxford University Press, pp. $1-23$.

Manteli, V. 2008. 'The Acharnians' Revival on Modern Greek Stage: Translation and Performance. Athens: University of Athens PhD thesis. [in Greek]

Manteli, V. (2011). 'Transferring Aristophanes' Religious Registers into Modern Greek and English Versions: The Case of (Re)constructing the Religious Humour of Aristophanes' Comedy Acharnians in Greek and English Target-texts', in H. Geybels \& W. Van Herck, (eds.), Humour and Religion: Challenges and Ambiguities, London: Continuum, pp. 85-107.

Robson, J. (2008). 'Translating (Aristophanic) Humour', in L. Hardwick \& Ch. Stray, (eds.), A Companion to Classical Receptions, Oxford: Blackwell, pp. 168-182.

Rau, P. (1967). Paratragodia. Untersuchung einer komischen Form des Aristophanes. München: C. H Beck'sche Velagsbuchhandlung.

Russo, C. F. (1994) [1962]. Aristophanes. An Author for the Stage, trans. Kevin Wren, London \& New York: Routledge.

Silk, M. (2000). The definition of comedy. Oxford: Oxford University Press.

Silk, M. (2007). 'Translating/Transposing Aristophanes', in E. Hall \& A. Wrigley, (eds.), Aristophanes in Performance 421 BC-AD 2007, London: Modern Humanities Research Association and Maney Publishing/Legenda, pp. 287-308.

Slater, N.W. (2002). Spectator Politics. Metatheatre and Performance in Aristophanes. Philadelphia: University of Pennsylvania Press.

Stephanopoulos, Th. (2011). 'Modern Greek Translations of Ancient Greek Tragedies: Some Observations and Questions', Logeion. A Journal of Ancient Theatre 1, pp. 307-317, http://www.logeion.upatras.gr/images/Stephanopoulos_Metaphrase_tragwdias.pdf (accessed 27 June 2012). [in Greek]

Thiercy, P. (2001). O Aristophanis kai i archaia komodia [Aristophane et l' ancieenne comédie], trans. G. F. Galanis. Athens: Patakis. [in Greek]

Tsakona, V. (2004). Humour in written narratives. A linguistic approach. Athens: University of Athens Ph.d thesis. [in Greek]

Van Steen, G. A. H. (2000). Venom in Verse: Aristophanes in Modern Greece. Princeton/NJ: Princeton University Press.

Venuti, L. (2000). 'Translation, community, utopia', in L. Venuti, (ed.), The Translation Studies Reader. London \& New York: Routledge. 
Walton, J. M. (2006). Found in Translation. Greek drama in English. Cambridge: Cambridge University Press.

Walton, J. M. (2008). ' 'An Agreeable Innovation': Play and Translation', in A. Lianeri and V. Zajko, (eds.), Translation \& the Classic. Identity as Change in the History of Culture, Oxford and New York: Oxford University Press, pp.261-277. 